\title{
Leasing und das Kreditwesengesetz
}

Das von Leasinggesellschaften betriebene Finanzierungsleasing gehört gemäß $\S 1$ Abs. 1a Nr. $10 \mathrm{zu}$ den aufsichtspflichtigen und damit genehmigungspflichtigen Finanzdienstleistungen. Ferner fällt darunter auch die Verwaltung von Objektgesellschaften im Sinne von $\S 2 A^{*}$ bs. 6 Kreditwesengesetz. Refinanziert ein Kreditinstitut den Leasinggeber durch Herauslegung von Krediten, gegebenenfalls gegen Beiziehung von Sicherheiten - z. B. sicherungshalber Abtretung der Leasingforderungen oder Sicherungsübereignung des Leasinggutes -, so handelt es sich um ein Kreditgeschäft nach $\S 1$ Abs. 1 Kreditwesengesetz. 